\title{
HUBUNGAN KARAKTERISTIK PERAWAT DENGAN PERILAKU CARING
}

\author{
Wisnu Tri Anggoro, Qurrotul Aeni ${ }^{1}$, Istioningsih ${ }^{1}$ \\ ${ }^{1}$ Program Studi Ilmu Keperawatan, Sekolah Tinggi Ilmu Kesehatan Kendal \\ istioningsih.ns@gmail.com
}

\begin{abstract}
ABSTRAK
Perilaku caring perawat penting dalam melakukan asuhan keperawatan, karena perawat tidak hanya dituntut untuk melakukan skill atau keterampilan dan pengetahuan saja. Perilaku caring perawat kepada pasien berdampak besar bagi layanan rumah sakit karena akan menimbulkan kepuasan pasien. Caring pada dasarnya perilaku perawat yang dipengaruhi oleh karakteristik perawat. Penelitian ini untuk mengetahui hubungan karakteristik perawat dengan perilaku caring perawat di RSUD Dr. H. Soewondo Kendal. Penelitian ini menggunakan desainkorelasional dengan pendekatancross sectional. Sampel dalam penelitian ini diambil dengan menggunakan Proportionate Stratified Random Sampling sebanyak132 perawat di RSUD Dr. H. Soewondo Kendal. Alat penelitian menggunakan kuesionerkarakteristik danCaring Behavior Investment (CBI) Questionnaire yang dianalisis secara univariat dan bivariat menggunakan uji chi square. Hasil penelitian ini menunjukkan ada hubungan yang signifikan antara umur $\left(p_{\text {value }}=0,000\right)$, dan masa kerja $\left(p_{\text {value }}=0,001\right)$ dengan perilaku caring perawat, sedangkan jenis kelamin $\left(p_{\text {value }}=0,107\right)$, pendidikan $\left(p_{\text {value }}=0,055\right)$, dan status pernikahan $\left(p_{\text {value }}=0,117\right)$ tidak menunjukkan hubungan yang signifikan. Usia yang lebih dewasa dan semakin lama masa kerja perawat maka semakin baik perilaku caring perawat, sedangkan jenis kelamin, pendidikan, dan status pernikahan tidak membedakan perilaku caring perawat. Peneliti selanjutnya diharapkan mengembangkan faktor internal dan eksternal perawat.
\end{abstract}

Kata kunci: Karakteristik Perawat, Perilaku Caring

\section{RELATIONSHIP OF CARE CHARACTERISTICS WITH CARING BEHAVIOR}

\begin{abstract}
Nurses caring behavior important in nursing care, as nurses are not only required to perform the skill or skills and knowledge alone. The behavior of the nurses caring for patients with major implications for hospital services because it will cause the patient satisfaction. Caring nurse whose behavior is basically influenced by the characteristics of nurses. The purpose of this study to determine the characteristics of the relationship with the nurse caring behaviors of nurses in hospitals Dr. H. Soewondo Kendal. This study uses a correlational design with cross sectional approach. The sample in this study were taken by using Proportionate Stratified Random Sampling 132 nurses at the Hospital Dr. H. Soewondo Kendal. Research tool questionnaire characteristics and Caring Behavior Investment (CBI) Questionnaire were analyzed by univariate and bivariate using chi square test. The results showed no significant relationship between age $\left(p_{\text {value }}=0.000\right)$, and the work period $\left(p_{\text {value }}=\right.$ $0.001)$ with the nurse caring behaviors, whereas gender $\left(p_{\text {value }}=0.107\right)$, education $\left(p_{\text {value }}=0.055\right)$, and marital status $\left(p_{\text {value }}=0.117\right)$ did not show a significant relationship. The more mature age and the longer the nurse's working period the better the caring behavior of the nurse, while the sex, education, and marital status do not distinguish the caring behavior of the nurse. The researcher is then expected to develop internal and external factors of the nurse.
\end{abstract}

Keywords: Characteristics of Nurses, Caring Behaviors

\section{PENDAHULUAN}

Pelayanan keperawatanyang komprehensif memerlukan kemampuan seorang perawat dalam memperhatikan pasien, ketrampilan intelektual, teknikal dan interpersonal yang tercermin dalam perilaku caring (Sitorus,
2011). Caring merupakan kepedulian interpersonal seorang yang berprofesi sebagai perawat dalam memberikan keamanan dan perhatian serta empati pada pasien. Perilaku caring ditunjukkan dengan mengakui keberadaan manusia (assurance of human 
presence), menanggapi dengan rasa hormat (respectful), pengetahuan dan keterampilan profesional (professional knowledge and skill), menciptakan hubungan positif (positive connectedness), perhatian terhadap yang dialami orang lain (attentiveness to the other's experience) (George, 2010).

Kenyataan yang dihadapi masih banyak rumah sakit pemerintah maupun swasta yang memusatkan diri pada pengobatan pasien saja. Keberhasilan ilmu pengetahuan dan teknologi menyebabkan perawat hanya memberikan perhatian pada tugas-tugas mengobati dari pada merawat. Perawat tidak banyak mendengarkan keluhan pasien dan memberikan dukungan empati karena delegasi lebih diberikan untuk tugas-tugas dokter, sehingga perilaku caring dalam praktik asuhan keperawatan sehari-hari belum banyak diterapkan oleh perawat (Tomey, 2013).

Penelitian Hidayati (2013) menghasilkan bahwa asuhan keperawatan dilihat dari sikap caring tampak adanya kondisi yang kurang positif, terlihat pada proporsi caring perawat yang baik $14 \%$, cukup 69\%, dan kurang17\%. Hasil penelitian yang sama dilaporkan oleh Rosidah (2012) bahwa distribusi perawat yang caring $49,7 \%$ dan yang tidak caring $50,3 \%$. Penelitian oleh Windarini (2014) menghasilkan sikap caring perawat hanya sebagai pemahaman saja, tetapi belum dapat diaplikasikan secara maksimal dalam pelayanan kepada pasien atau dapat dikatakan masih rendah.

Rendahnya perilaku caring yang diterapkan oleh perawat membawa persepsi akan rendahnya mutu dan kualitas asuhan keperawatan yang diberikan. Hal ini dikarenakan perilaku caring akan selalu dinilai oleh pasien sebagai salah satu penentu akan kepuasan pasien, dan sebagai salah satu indikator keberhasilan pelayanan kesehatan (Supriyanto, 2010). Caring juga merupakan fokus pemersatu untuk praktek keperawatan, dan sangat penting untuk tumbuh kembang, memperbaiki dan meningkatkan kondisi lingkungan pekerjaan (Burnard P. 2009).

Perilaku perawat yang berlandaskan pada caring dapat memberikan kepuasan pada pasien. Penelitian yang dilakukan oleh Abdul (2013) tentang hubungan perilaku caring dengan tingkat kepuasan pasien menunjukkan bahwa perilaku caring yang baik pada perawat dalam memberikan asuhan keperawatan menciptakan sebagian besar kepuasan pada pasien terhadap pelayanan asuhan keperawatan. Perawat yang caring mempunyai peluang 4,92 kali untuk memberikan kepuasan pasien dibanding yang kurang caring. Perilaku caring perawat dijadikan penilaian kinerja untuk memenuhi kepuasan pasien (Sukesi, 2013). Hal ini membuktikan bahwa perilaku caring sangat dibutuhkan dalam menciptakan pelayanan perawatan yang bermutu dan berkualitas (Sitorus, 2011).

Akreditasi paripurna menuntut kualitas akan pelayanan keperawatan berkualitas di Rumah Sakit Umum Daerah Dr. H. Soewondo Kendal, yang salah satunya melalui praktik caring perawat yang tinggi.Namun penerapan perilaku caring oleh perawat masih menjadi permasalahan yang harus terus dikaji ulang.Survey kepuasan pasien tahun 2015 disebutkan indek kepuasan masyarakat (IKM) dilihat dari pelayanan penunjang, pelayanan rawat jalan, pelayanan rawat inap, dan loket dikategorikan baik yaitu IKM 74,99. Indeks tersebut merupakan hal yang membanggakan, namun belum mencapai target capaian rumah sakit dengan standar IKM > 90\%. Hal tersebut menunjukkan bahwa kualitas pelayanan masih belum mencapai standar IKM atau masih rendah, yang salah satu faktornya adalah perilaku caring perawat (RSUD Dr. Soewondo Kendal, 2016).

Robbins (2010) menyatakan bahwa caring pada dasarnya merupakan perilaku perawat, sehingga caring tersebut pada dasarnya tergantung dari karakteristik individu perawat. Penelitian yang dilakukan oleh Susanti (2013) menghasilkan bahwa karakteristik perawat yang meliputi umur, tingkat pendidikan, lama kerja memiliki hubungan yang signifikan dengan motivasi perawat dalam pemenuhan kebutuhan kebersihan diri pasien. Penelitian oleh Kumajas (2014) juga menghasilkan menunjukan terdapat hubungan yang signifikan dari masing-masing karakteristik individu yaitu umur, pendidikan, masa kerja, dan status pernikahan dengan kinerja perawat.

Studi pendahuluan, dari 9 perawat terdapat 5 perawat memiliki perilaku caring yang kurang kepada pasien. Hal tersebut terjadi dimana kurangnya komunikasi terapeutik perawat terhadap pasien, perawat kurang dalam membina hubungan saling percaya dengan pasien, lebih banyak melakukan tindakan medis (kedokteran) dibandingkan tindakan 
keperawatan secara holistik, serta uraian tugas perawat pelaksana yang kurang jelas. Kondisi yang seperti itu pada akhirnya menimbulkan anggapan pasien terhadap perawat yang kurang baik.Penelitian ini bertujuan untuk mengetahui hubungan karakteristik perawat dengan perilaku caring pada perawat di RSUD Dr. $\mathrm{H}$. Soewondo Kendal.

\section{METODE}

Desain penelitian ini menggunakan deskriptif korelasionaldengan pendekatan secara cross sectional.Populasi dalam penelitian ini adalah semua perawat di RSUD Dr. H. Soewondo Kendal. Jumlah sampel dalam penelitian ini sebanyak 132responden dengan pengambilan sampel secaraProportionate Stratified Random Samplingyaitu dari ruang Anggrek sejumlah 16 perawat, ruang Bogenvil sejumlah 12 perawat, ruang Flamboyan I sejumlah 17 perawat, ruang Flamboyan II sejumlah 19 perawat, ruang Cempaka I sejumlah 13 perawat, ruang Cempaka II sejumlah 19 perawat, ruang Kenanga sejumlah 22 perawat, ruang Melati sejumlah 19 perawat, ruang Dahlia sejumlah 23 perawat, ruang Mawar 4 perawat, dan ruang ICU 17 perawat.Penelitian dilakukan pada bulan Februari 2017dengan alat penelitian menggunakan kuesionerkarakteristik perawat, dan Caring Behavior Investment (CBI) Questionnaire. Data dianalisis menggunakan ujispearman rho danchi square test.

\section{HASIL}

Hasil penelitian dapat dilihat pada tabel berikut ini.

1. Hubungan Usia dengan Perilaku Caring Perawat

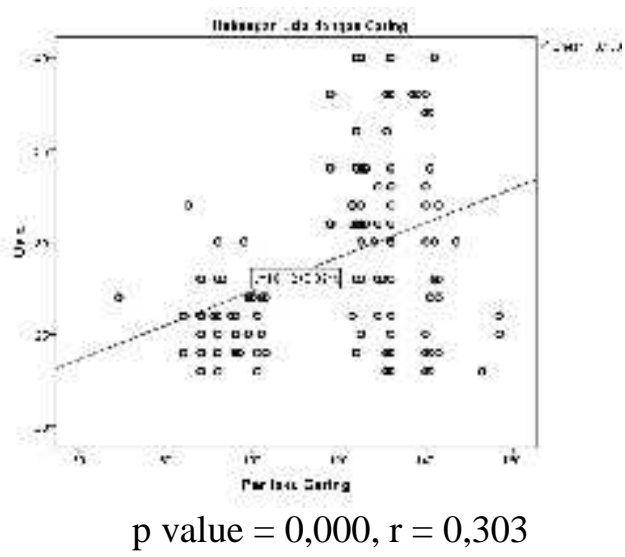

Gambar 1 Hubungan antara Usia dengan Perilaku Caring Perawat

Tabel 1 .

Hubungan antara Jenis Kelamin dengan Perilaku Caring Perawat

\begin{tabular}{|c|c|c|c|c|c|c|}
\hline \multirow{3}{*}{$\begin{array}{c}\text { Jenis } \\
\text { Kelamin }\end{array}$} & \multicolumn{4}{|c|}{ Perilaku Caring } & \multirow{3}{*}{$P$ value } & \multirow{3}{*}{$\begin{array}{c}\text { OR } \\
(\mathrm{CI} 95 \%)\end{array}$} \\
\hline & \multicolumn{2}{|c|}{ Baik } & \multicolumn{2}{|c|}{ Kurang Baik } & & \\
\hline & $\mathrm{f}$ & $\%$ & $f$ & $\%$ & & \\
\hline Laki-Laki & 39 & $70,9 \%$ & 16 & $29,1 \%$ & (107 & 1090 \\
\hline Perempuan & 44 & $57,1 \%$ & 33 & $42,9 \%$ & $0,10 /$ & $1,8<\delta$ \\
\hline
\end{tabular}

Tabel 2.

Hubungan antara Pendidikan dengan Perilaku Caring Perawat

\begin{tabular}{|c|c|c|c|c|c|}
\hline \multirow{3}{*}{ Pendidikan } & \multicolumn{4}{|c|}{ Perilaku Caring } & \multirow{3}{*}{$P$ value } \\
\hline & \multicolumn{2}{|c|}{ Baik } & \multicolumn{2}{|c|}{ Kurang Baik } & \\
\hline & $f$ & $\%$ & $\mathrm{f}$ & $\%$ & \\
\hline D3 & 34 & $51,5 \%$ & 32 & $48,5 \%$ & \\
\hline SI & 15 & $100 \%$ & 0 & $0,0 \%$ & 0,055 \\
\hline Ners & 34 & $66,7 \%$ & 17 & $33,3 \%$ & \\
\hline
\end{tabular}


Tabel 3.

Hubungan antara Status Pernikahan dengan Perilaku Caring Perawat

\begin{tabular}{|c|c|c|c|c|c|c|}
\hline \multirow{3}{*}{ Status Pernikahan } & \multicolumn{4}{|c|}{ Perilaku Caring } & \multirow{3}{*}{$P$ value } & \multirow{3}{*}{$\begin{array}{c}\text { OR } \\
\text { (CI 95\%) }\end{array}$} \\
\hline & \multicolumn{2}{|c|}{ Baik } & \multicolumn{2}{|c|}{ Kurang Baik } & & \\
\hline & $\mathrm{f}$ & $\%$ & $\mathrm{f}$ & $\%$ & & \\
\hline Belum Menikah & 26 & $54,2 \%$ & 22 & $45,8 \%$ & 0117 & 0560 \\
\hline Menikah & 57 & $67,9 \%$ & 27 & $32,1 \%$ & 0,111 & 0,500 \\
\hline
\end{tabular}

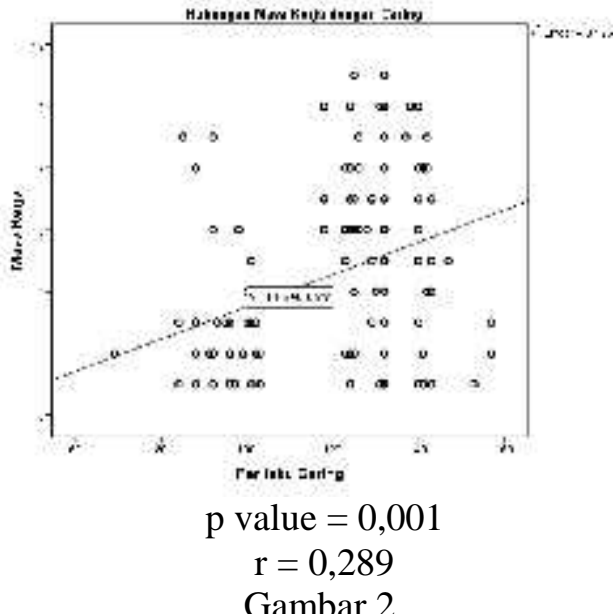

Hubungan antara Masa Kerja dengan Perilaku Caring Perawat

\section{PEMBAHASAN}

Hasil penelitian menunjukkan ada hubungan positif antara usia perawat dengan perilaku caring perawat dengan uji spearman rho diperoleh nilai pvalue $=0,000\left(\rho_{\text {value }}<0,05\right)$, dan nilai koefisien korelasi sebesar 0,303 . Usia sangat berpengaruh terhadap kinerja untuk berperilaku caring, dimana semakin tua usia perawat maka dalam menerima sebuah pekerjaan akan semakin bertanggung jawab dan berpengalaman. Hal ini akan berdampak pada kinerja perawat untuk berperilaku caring pada pasien semakin baik pula (Siagian, 2010). Sejalan dengan penelitian oleh Ismael (2009) yang menghasilkan bahwa usia berkaitan erat dengan tingkat kedewasaan atau maturitas perawat. Semakin bertambah usia seseorang semakin meningkat pula kedewasaan seseorang, demikian juga psikologisnya akan menunjukkan kematangan jiwa.

Seseorang selama masa dewasa awal biasanya lebih perhatian pada pengejaran pekerjaan dan sosial. Selama periode ini individu mencoba untuk membuktikan status sosioekonominya (Potter \& Perry, 2010). Semakin bertambahnya usia seseorang, maka individu tersebut akan memotivasi dirinya sendiri agar lebih baik lagi status sosioekonominya, yaitu dengan cara bekerja. Seperti pada penelitian yang dilakukan oleh Windarini (2014) menghasilkan perawat yang lebih dewasa memiliki perilaku caring yang lebih tinggi pada keluarga pasien karena memiliki rasa tanggungjawab yang lebih tinggi.

Meskipun usia akan mempengaruhi pendewasaan seseorang, namun tidak selamanya orang tersebut akan mempunyai caring yang tinggi. Seperti pada penelitian yang dilakukan oleh Suryani (2010) menghasilkan bahwa lingkungan kerja akan mempengaruhi caring perawat. Lingkungan yang kurang mendukung membuat perawat merasa jenuh dalam bekerja (Zhang \& Zheng, 2009). Peneliti berpendapat bahwa semakin bertambahnya usia seseorang, maka akan mempengaruhi caring seorang perawat, tetapi usia tidak bisa menjamin caring perawat menjadi baik dan buruk atau tinggi dan rendah. Semua tergantung pada individu masing-masing

Hasil penelitian menunjukkan sebanyak 39 $(70,9 \%)$ dari 55 responden laki-laki dan berperilaku caring dengan baik. Sebanyak 44 $(57,1 \%)$ dari 77 responden perempuan dan berperilaku caring dengan baik. Hal ini menunjukkan mayoritas perawat laki-laki maupun perempuan memiliki perilaku caring dengan baik, jenis kelamin tidak membedakan perilaku caring perawat. Hasil analisis uji chi square didapatkan pula nilai $\mathrm{p}$ value $=0,107(\mathrm{p}$ 
value $>0,05)$, yang artinya tidak ada hubungan antara jenis kelamin dengan perilaku caring perawat.

Menurut pendapat Edyana (2008) mengungkapkan bahwa ada perbedaan kemampuan antara laki-laki dan perempuan dalam hubungan antar manusia, dimana perempuan memiliki kepekaan yang lebih tinggi dibandingkan dengan pria. Psikologis tersebut seharusnya menjadikan perempuan memiliki caring yang lebih tinggi dibandingkan laki-laki. Hal tersebut berbeda dengan penelitian ini yang menunjukkan perawat baik laki-laki maupun perempuan sebagian besar sama-sama memiliki perilaku caring yang baik.

Hasil ini sama halnya dengan pendapat menurut Robbins \& Judge (2010) yang mengungkapkan bahwa laki-laki lebih agresif dan lebih besar kemungkinan dalam memiliki pengharapan untuk sukses dibandingkan dengan perempuan. Hal tersebut menjadikan laki-laki memiliki kinerja yang lebih baik dibandingkan dengan perempuan. Terkait dengan kinerja tersebut, maka laki-laki juga dapat berperilaku caring lebih baik dibandingkan perempuan.

Sejalan dengan penelitian yang dilakukan oleh Susanti (2013) tentang hubungan karakteristik perawat dengan motivasi perawat dalam pemenuhan kebutuhan kebersihan diri pasien, juga menghasilkan bahwa perawat laki-laki maupun perempuan memiliki motivasi yang baik dalam memenuhi kebutuhan pasien. Sejalan dengan penelitian Nurimi (2010) yang menyimpulkan bahwa tidak terdapat hubungan yang bermakna antara jenis kelamin perawat dengan motivasi kerja perawat. Peneliti berpendapat, bahwa sebagai seorang perawat, laki-laki dan perempuan memiliki peran yang sama pada saat berada dalam lingkungan kerja, sehingga tidak bisa dibedakan mana yang caring lebih baik.

Hasil penelitian menunjukkan kategori perilaku caring berdasarkan masing-masing pendidikan perawat. Sebanyak $49(60,5 \%)$ dari 81 responden $\mathrm{D} 3+\mathrm{S} 1$ dan berperilaku caring dengan baik. Sebanyak $34(66,7 \%)$ dari 66 responden Ners dan berperilaku caring dengan baik. Berdasarkan hasil analisis uji chi square didapatkan nilai $\mathrm{p}$ value $=0,055$, Karena nilai $\mathrm{p}$ value $>0,05$. Maka dapat disimpulkan tidak ada hubungan antara pendidikan dengan perilaku caring perawat di RSUD Dr. H. Soewondo Kendal.
Siagian (2010) mengungkapkan bahwa pengetahuan yang didapatkan seseorang dalam pendidikan merupakan pengalaman yang berfungsi untuk mengembangkan kemampuan dan kualitas keperibadian seseorang. Semakin tinggi pendidikan seseorang, maka semakin besar pula keinginan untuk memanfaatkan pengetahuan dan keterampilan. Pendidikan berpengaruh terhadap pola pikir individu, sedangkan pola pikir berpengaruh terhadap perilaku seseorang, dengan kata lain pola pikir seseorang yang berpendidikan rendah akan berbeda dengan pola pikir seseorang yang berpendidikan tinggi

Tingkat pendidikan yang lebih tinggi, pada umumnya menyebabkan orang lebih mampu dan bersedia menerima posisi yang bertanggung jawab (Notoatmodjo, 2012). Pendidikan keperawatan mempunyai pengaruh besar terhadap kualitas pelayanan keperawatan. Pendidikan yang tinggi dari seorang perawat akan memberi pelayanan yang optimal (Asmadi, 2008).Semakin tinggi tingkat pendidikan seseorang, maka semakin bertambah pula pengetahuan yang dimiliki, semakin bertambah pula skill yang dimikili. Perawat dengan jenjang pendidikan yang lebih tinggi akan merasa percaya diri dan mulai menunjukkan bahwa peningkatan pendidikannya setara dengan kemampuan yang dimilikinya, hal seperti ini memotivasi perawat untuk dapat lebih meningkatkan kualitas layanan asuhan keperawatan khususnya kebersihan diri pasien.

Hasil penelitian ini menunjukkan sebanyak 26 $(54,2 \%)$ dari 48 responden yang belum menikah dan berperilaku caring dengan baik. Sebanyak $47(67,9 \%)$ dari 84 responden yang sudah menikah dan berperilaku caring dengan baik. Hal tersebut menunjukkan bahwa perawat yang sudah menikah maupun yang belum menikah sebagian besar sama-sama memiliki perilaku caring yang baik. Berdasarkan hasil analisis uji chi square didapatkan nilai $\mathrm{p}$ value $=0,117$ ( $\mathrm{p}$ value $>0,05$ ), yang artinya tidak ada hubungan antara status pernikahan dengan perilaku caring perawat di RSUD Dr. H. Soewondo Kendal.

Hal ini bertentangan dengan pendapat Robbins (2010) yang mengungkapkan bahwa pernikahan mampu meningkatkan tanggung jawab yang dapat membuat suatu pekerjaan menjadi berharga. Pendapat tersebut dapat dikatakan bahwa perawat yang berstatus menikah 
seharusnya lebih bertanggungjawab pada kebutuhan pasien dengan lebih caring pada pasien. Namun hasil penelitian ini perawat yang berstatus menikah maupun belum menikah memiliki perilaku caring yang sama.

Berbeda pula dengan penelitian yang dilakukan oleh Kumajas (2014) tentang hubungan karakteristik dengan kinerja perawat menghasilkan bahwa terdapat hubungan antara status pernikahan dengan kinerja perawat. Perilaku caring juga termasuk dalam kinerja perawat. Penelitian tersebut menjelaskan bahwa pernikahan menyebabkan peningkatan tanggung jawab dan pekerjaan tetap menjadi lebih berharga dan penting, sehingga perawat yang berstatus menikah mempunyai tanggungjawab yang lebih tinggi dibandingkan dengan perawat yang belum menikah.

Peneliti berasumsi perilaku caring perawat yang menikah maupun yang belum sama saja. Perawatan yang diberikan kepada pasien yang dirawat di RSUD Dr. Soewondo Kendal tidak berbeda dan diberikan apa adanya sesuai dengan kebiasaan sebelumnya yang pernah dilakukan dan budaya kerja yang ada di rumah sakit tersebut, sehingga status pernikahan yang dimiliki perawat tidak mempengaruhi perilaku caring perawat.

Hasil penelitian menunjukkan ada hubungan positif antara masa kerja perawat dengan perilaku caring perawat yang didukung dengan uji spearman rho diperoleh nilai pvalue $=0,001$ $\left(\rho_{\text {value }}<0,05\right)$, dan nilai koefisien korelasi sebesar 0,289. Artinya terdapat hubungan antara masa kerja dengan perilaku caring perawat di RSUD Dr. H. Soewondo Kendal dengan arah positif dan kekuatan hubungan sedang. Berarti semakin lama masa kerja perawat maka semakin baik perilaku caring perawat, dibandingkan dengan perawat yang masa kerjanya masih baru.

Semakin lama seseorang bekerja, maka keterampilan dan pengalamannya juga semakin meningkat (Robbins \& Judge, 2010). Pengalaman merupakan salah satu cara kepemilikan pengetahuan yang dialami seseorang dalam kurun waktu yang tidak ditentukan. Secara psikologis seluruh pemikiran manusia, kepribadian dan temperamen ditentukan pengalaman indera. Pikiran dan perasaan bukan penyebab tindakan tapi oleh penyebab masa lalu. Pengalaman yang dialami seseorang akan ikut membentuk dan mempengaruhi penghayatan terhadap stimulus sosial. Tanggapan akan menjadi salah satu dasar terbentuknya sikap (Azwar, 2012). Sehingga pengalaman yang lebih banyak akan meningkatkan perilaku caring perawat.

Kinerja masa lalu cenderung dikaitkan dengan keluarnya dalam posisi baru, maka senioritas itu sendiri tidaklah merupakan peramal yang baik produktivitasnya, jika semua hal sama, tidak ada alasan untuk meyakini bahwa orang-orang yang telah lama bekerja dalam suatu pekerjaan akan lebih baik produktivitasnya dibandingkan dengan mereka yang belum bekerja (Robbins \& Judge, 2010). Seperti halnya dengan penelitian yang dilakukan oleh Sukesi (2013) yang menghasilkan bahwa perilaku caring perawat yang lebih senioritas lebih tinggi dibandingkan dengan perawat yang pengalaman kerjanya masih baru.

Perawat yang mempunyai masa kerja lebih lama tentunya mempunyai pengalaman yang lebih banyak. Pengalaman ini dapat berguna ketika perawat menghadapi masalah terkait masalah kebersihan diri pasien, misalnya saja pada pasien bedrest. Pasien pada awalnya mungkin hanya menderita penyakit $\mathrm{X}$, tetapi karena tidak diperhatikan kebersihan dirinya, pasien mengalami gangguan pada kulitnya, misalnya gatal-gatal. Hal seperti inilah yang dapat memotivasi perawat yang berpengalaman lebih lama untuk melakukan tindakan kebersihan pasien untuk dapat meminimalisir terjadinya masalah kesehatan lainnya

\section{SIMPULAN DAN SARAN \\ Simpulan}

Perawat di RSUD Dr. H. Soewondo Kendal rata-rata berusia29 tahun, mayoritas perempuan (58,3\%), mayoritas berpendidikan D3 (50\%), mayoritas berstatus menikah $(63,6 \%)$, dan ratarata lama kerja adalah4,45 tahun.Perawat sebagian besar berperilaku caring dengan baik $(62,9 \%)$. Terdapat hubungan yang signifikan antara umur $\left(p_{\text {value }}=0,000\right)$, dan masa kerja $\left(p_{\text {value }}=0,001\right)$ dengan perilaku caring perawat, sedangkan jenis kelamin $\left(p_{\text {value }}=0,107\right)$, pendidikan $\left(p_{\text {value }}=0,055\right)$, dan status pernikahan $\left(p_{\text {value }}=0,117\right)$ tidak menunjukkan hubungan yang signifikan. Usia yang lebih dewasa dan semakin lama masa kerja perawat maka semakin baik perilaku caring perawat, sedangkan jenis kelamin, pendidikan, dan status pernikahan tidak membedakan perilaku caring perawat. 


\section{Saran}

Peneliti selanjutnya diharapkan mengembangkan faktor internal dan eksternal perawat.RSUD Dr. H. Soewondo Kendal diharapkan menjaga kompetensi caring perawat dengan tetap melakukan penyegaran maupun bimbingan kepada perawat mengenai caring perawat, sehingga kualitas pelayanan keperawatan tetap terjaga dengan baik

\section{DAFTAR PUSTAKA}

Abdul. (2013). Hubungan Perilaku Caring Perawat Dengan Tingkat Kepuasan Pasien Rawat Inap Rumah Sakit. Jurnal Keperawatan Universitas Hasanudin.

Alligood, M.R. (2010). Nursing Theory: Utilization and application. Missouri: Mosby Elsevier. Watson, J. (2007) Caring theory define. http://www.nursing.uc.denver.edu/fac ulty/jwimplications.htm. Diakses 30 oktober 2016.

Barnum, J.B.S. (2011). Nursing theory: Analysis, application, evaluation. (5th Ed). Philadelphia: Lippincott.

Bastiansyah (2014). Pengaruh Tingkat Kepuasan Perawat Terhadap Perilakucaring Di Ruang Rawat Inap Rsud Kartini Jepara. pmb.stikestelogorejo.ac.id/ejournal/in dex.php/ilmukeperawatan/article/view /2. diakses 28 November 2016.

Burtson, P.L., \& Stichler, J.F. (2010). Nursing work environment and nurse caring: relationship among motivational factors. Journal of Advanced Nursing. 66(8), 18191831.doi: $\quad 10,1111 / j .1365-$ 2648.2010.05336.x

Conny Tan. (2016). Faktor-Faktor Yang Mempengaruhi Perilaku Caring Perawat Dalam Menangani Pasien Kritis Di Ruang ICU, HCU RSUD Dok II Jayapura Dan ICU RSUD Abepura Di Provinsi Papua. http://pustaka.unpad.ac.id/archives/11718 9. Diakses15 Oktober 2016.
Hidayati. (2013). Hubungan Perilaku Caring Perawat Dengan Tingkat Kecemasan Pasien Rawat Inap Di Rumah Sakit PKU Muhammadiyah Surakarta. Jurnal Universitas Muhammadiyah Surakarta.

Kumajas. (2014). Hubungan Karakteristik Individu Dengan Kinerja Perawat Di Ruang Rawat Inap Penyakit Dalam RSUD Datoe Binangkang Kabupaten Bolaang Mongondow. Jurnal Universitas Sam Ratulangi manado

Kusumarini (2016). Faktor - Faktor Yang Mempengaruhi Perilaku Caring Perawat Di Ruang Sulaiman 3 - 4 Rs Roemani Muhammadiyah Semaranghttp://glib.unimus.ac.id.

Minarsih, M. (2011). Hubungan BebanKerjaPerawat denganProduktivitas Kerja Perawat diIRNA Non Bedah (PenyakitDalam) RSUP. Dr. M. DjamilPadang. Fakultas Keperawatan Universitas Andalas

April2014.http://repository.unand.ac.i d/17981pdf.

Nurhayati (2016). Analisis Hubungan Perilaku Caring dengan Kinerja Perawat Pelaksana Menerapkan Prinsip Etik Keperawatan dalam Asuhan Keperawatan di Rumah Sakit Bhayangkara Mappa Oudang Makassar.http//

PoltekkesKemenkesPangkalpinang191554-1-SM.pdf.I

Potter, P.A., \& Perry, A.G. (2010). Buku Ajar Fundamental Keperawatan. Jakarta: EGC.

Prihandhani. (2015). Hubungan Faktor Individu Dan Budaya organisasi Dengan Perilaku Caringperawat Pelaksana Di Ruang Rawat Inap Rumah Sakit Umum Ganesha Gianyar. http//unud-1259-1088783-tesis igaa sherlyna prihandhani.diakses 8 Oktober 2016.

Robbins, S. \& Judge, Y. (2010). Perilaku organisasi. (Terj. D. Angelica, $R$. Cahyani, dan A. Rosyid) Edisi 12. Jakarta: Salemba Empat. 
Rosidah. (2012). Persepsi Orang Tentang Perilaku Caring Perawatan pada Pelaksanaan Asuhan Keperawatan di Ruang Rawat Inap Anak RSUD Serang. Jurnal UIN Syarif Hidayatullah Jakarta.

Siagian, S. (2010). Kiat meningkatkan produktivitas kerja. Jakarta: Rineka Cipta

Sitorus, R. (2011). Model Praktek Keperawatan Professional di Rumah Sakit. Jakarta: EGC.

Sukesi. (2013). Upaya Peningkatan Caring Perawat Terhadap Kepuasan Pasien Diruang Rawat Inap RS Permata Medika Semarang. Jurnal Managemen Keperawatan . Volume 1, No. 1, Mei 2013; 15-24.
Supriyanto S., dan M. Ernawati. (2010). Pemasaran Industri Jasa Kesehatan. Yogyakarta : ANDI.

Watson. (2009). Assesing \& Measuring Caring in Nursing and Health Sciences. Canada: Siger Publishing Company.

Windarini. (2014). Sikap Caring Perawat dalam Memberikan Asuhan Keperawatan pada Pasien di Ruang Intensive Care Unit RSUD Dr. Soedirman Mangun Sumarso Kabupaten Wonogiri. Jurnal STIKES Kusuma Husada Surakarta. 